\title{
The Antigen of Bordetella pertussis that Induces Bactericidal Antibody and its Relationship to Protection of Mice
}

\author{
By J. P. ACKERS AND JEAN M. DOLBY \\ The Lister Institute of Preventive Medicine, Elstree, Hertfordshire
}

(Accepted for publication 22 November 1971)

\begin{abstract}
SUMMARY
The ability to protect mice against intracerebral infection and to elicit, after one dose, complement-mediated bactericidal antibody capable of killing a mousevirulent phase I strain in vitro, was tested in seven cultures of Bordetella pertussis: three typical phase I strains; two strains grown in the presence of $0.5 \mathrm{mg}$ nicotinic acid $/ \mathrm{ml}$; one phase IV strain; and the atypical strain $\mathrm{I} 34$. The typical strains showed both activities; the nicotinic acid-grown and phase IV strains elicited high antibody titres, but did not confer protection, whereas strain I34 protected, but did not elicit bactericidal antibody.

Pyrogenic material extracted from dried organisms by hot phenol and water (lipopolysaccharide) was not antigenic in mice; however, with all strains, except I34, multiple doses of this material coupled to stromata or Escherichia coli conjugated protein elicited bactericidal and precipitating antisera in mice, although the mice were not protected.

Strain I34 contained approximately one quarter of the normal amount of endotoxin, as assayed in actinomycin D-sensitized mice, but was as effective as normal strains as an adjuvant for haemolysin production.
\end{abstract}

\section{INTRODUCTION}

The injection of killed Bordetella pertussis organisms intraperitoneally in a mouse will protect the animal against a subsequent intracerebral challenge by a virulent strain of the same organism; and vaccines which protect mice in this way are also able to protect children against natural infection (Medical Research Council report, 1956). The measurement of whooping-cough vaccine potency by the mouse-protection test is slow and requires large numbers of animals. The potency of vaccine might be more conveniently assayed by measuring its ability to elicit an easily measured antibody with a demonstrable relationship to protection.

Following an injection of a protective dose of vaccine, circulating antibodies appear in the mouse, including a complement-mediated bactericidal antibody, the properties of which were investigated (Dolby, I965; Dolby \& Vincent, 1965). Dolby \& Dolby (1969) suggested that this antibody is responsible for the protection of actively immunized mice.

Screening experiments on routine vaccines showed a good correlation between serum levels of bactericidal antibody and the degree of protection conferred on mice (A. P. Hunt, personal communication). This paper describes a more detailed examination of this correlation.

Some preliminary studies on the nature of the antigen which induces this complementmediated bactericidal antibody, active in vitro against serum-sensitive phase I Bordetella pertussis and referred to as the 'bactericidal antigen', are also reported. 


\section{METHODS}

Organisms. The strains of Bordetella pertussis were all obtained from the collection of freeze-dried cultures at Elstree: GL.29 I - a vaccine strain originally obtained from Glaxo Laboratories; D6229, D25525, D734-recently isolated strains used for routine vaccine production; I34-a nutritionally less exacting but protective strain originally obtained from Lederle Laboratories and used by Pillemer to prepare his cell-free vaccine (Pillemer, 1950; Pillemer, Blum \& Lepow, 1954); L84 - isolated from a case of whooping cough in Leeds in 1950; and L84 phase IV - a variant, obtained from L84, adapted by repeated subculture to grow on simple media. It grew well on nutrient agar and did not protect mice at a dose of $4 \times 10^{9}$ organisms per animal. These properties of phase IV organisms are not always stable (Leslie \& Gardner, I93I), and we have found that when newly reconstituted from the freeze-dried state they may grow poorly on nutrient agar and show traces of mouse-protective activity; typical phase IV properties are, however, regained after a few subcultures on nutrient agar. All phase IV organisms mentioned in this paper were maintained on nutrient agar and had been subcultured on the same medium at least five times since reconstitution.

Cultural conditions. Freeze-dried cultures of all strains except L84 phase IV were opened on to Bordet-Gengou medium, subcultured once at $37^{\circ}$ and then used to inoculate Cohen $\&$ Wheeler ( 1946$)$ medium (I00 ml), modified to contain $0.5 \% \mathrm{~L}$-glutamic acid (w/v) and $0 . \mathrm{I} \%$ peptone. Maintenance cultures of L84 phase IV were subcultured once on nutrient agar before inoculation into $100 \mathrm{ml}$ of liquid medium. The primary liquid cultures of all strains were shaken at $37^{\circ}$ for $24 \mathrm{~h}$ and then used to inoculate $500 \mathrm{ml}$ of the same medium in Glaxo flasks (ro ml inoculum/flask); the cultures were shaken for $40 \mathrm{~h}$ at $37^{\circ}$, killed by treatment with $0.1 \%$ formaldehyde at $4^{\circ}$ for $48 \mathrm{~h}$, centrifuged, and resuspended in phosphate buffered saline $(0.85 \% \mathrm{NaCl}+0.006 \mathrm{M}$-phosphate buffer, $\mathrm{pH} 7.2)$ plus $0.01 \%$ merthiolate. Vaccines were stored at $4^{\circ}$; before use they were suitably diluted in buffered saline+ merthiolate and heated at $56^{\circ}$ for 30 min to destroy heat-labile toxicity.

Bacterial concentrations in liquid cultures and vaccines were determined by visual comparison of opacity with the International Opacity Standard (Io International Units are equal to $10^{10}$ Bordetella pertussis organisms $/ \mathrm{ml}$ ).

Bacterial sonicate. The sonicate used in immunodiffusion plates was prepared by suspending bacteria in buffered saline to $\mathrm{I} \cdot 2 \times \mathrm{IO}^{12}$ organisms $/ \mathrm{ml}$ and exposing them to the full power of a Dawe Soniprobe (Dawe Instruments Ltd, Western Avenue, London, W.3), model I $130 \mathrm{~A}$, for $15 \mathrm{~min}$ in a water-cooled cell. The viscous product was centrifuged at $20000 \mathrm{~g}$ for $30 \mathrm{~min}$ at $4^{\circ}$ and the greenish-yellow supernatant liquid was stored at - I $5^{\circ}$ until required.

Nicotinic acid. Nicotinic acid was suspended in water; sufficient $4 \mathrm{~N}$-sodium hydroxide was added to dissolve the solid and the solution was diluted to $25 \mathrm{mg} / \mathrm{ml}$. The solution was autoclaved at $12 \mathrm{I}^{\circ}$ for $15 \mathrm{~min}$ and $10 \mathrm{ml}$ was added aseptically to $500 \mathrm{ml}$ of medium in a Glaxo flask, giving a final concentration of approximately $500 \mu \mathrm{g} / \mathrm{ml}$.

Tests for bactericidal antibody. Mice of Theiler's Original strain were used, and single or multiple doses of vaccine injected intraperitoneally. Whole cell vaccine was given in $0.5 \mathrm{ml}$ containing $2 \times 10^{9}$ organisms, and extracted antigens in 0.1 to $0.5 \mathrm{ml}$ containing 2 to $100 \mu \mathrm{g}$ as described. The mice were killed with coal gas 14 days after the last injection and were bled out at once from the heart. The blood was allowed to clot and, after standing overnight at $4^{\circ}$, sera were collected, pooled and inactivated at $56^{\circ}$ for $30 \mathrm{~min}$.

Bactericidal antibody levels were determined by a slight modification of the method previously described (Dolby \& Vincent, I965). Serial dilutions (usually fourfold) of the 
test serum were prepared in I \% Casamino acids (Difco). Fresh guinea-pig serum (unabsorbed and stored at $-15^{\circ}$ ) was used as a source of complement; it was diluted by a previously determined optimum factor (usually I/Io to $\mathrm{I} / 25)$ in I $\%(\mathrm{w} / \mathrm{v})$ bovine serum albumin (Armour, St. James', London, S.W.I) in buffered saline. The test organism was a $20 \mathrm{~h}$ Bordet-Gengou culture of Bordetella pertussis strain I8-323 (identical in all respects with the strain used for intracerebral infection of mice in the vaccine potency assay), suspended in $1 \%$ Casamino acids and diluted to contain $5 \times 10^{6}$ organisms $/ \mathrm{ml}$. The reaction mixture consisted of $0.2 \mathrm{ml}$ each of serum, complement and suspended organisms; after incubation at $37^{\circ}$ with gentle agitation for $45 \mathrm{~min}$, tenfold dilutions were made in I \% Casamino acids containing $7 \%(\mathrm{w} / \mathrm{v})$ sodium chloride. The high salt concentration inactivated the complement and prevented further killing of bacteria. Viable counts were determined by the method of Miles \& Misra (1938) on plates of modified Cohen \& Wheeler medium plus I \% $(\mathrm{w} / \mathrm{v})$ agar and $5 \%(\mathrm{v} / \mathrm{v})$ blood. Appropriate controls were included and the end-point was taken as the serum dilution killing $80 \%$ of the bacteria.

Potency assay. Mice vaccinated intraperitoneally with graded doses of vaccine were challenged intracerebrally $\mathrm{I} 4$ days later with $5 \times \mathrm{IO}^{4}$ Bordetella pertussis organisms of the mouse-virulent strain I8-323, harvested from a $20 \mathrm{~h}$ Bordet-Gengou plate into I $\%(\mathrm{w} / \mathrm{v})$ Casamino acids. Deaths were counted I 4 days later. The dose of vaccine protecting half the mice ( $\operatorname{mD} 50$ ) was determined by the method of Reed \& Muench (1938).

Endotoxin assay. Mice sensitized with actinomycin D (Cosmogen Lyovac; Merck, Sharp \& Dohme, Hoddesdon, Hertfordshire) are killed with very small amounts of endotoxin (Pieroni \& Levine, 1970). This method was used to assay the endotoxin content of Bordetella pertussis whole cell vaccines. The actinomycin D was injected intraperitoneally (Io $\mu \mathrm{g}$ in $0.25 \mathrm{ml}$ of buffered saline), into 15 to $17 \mathrm{~g}$ mice of the T.F. I strain. Graded doses of vaccine, also in $0.25 \mathrm{ml}$, were injected intraperitoneally 30 min later into groups of Io mice for each dose level of vaccine. Deaths were counted at seven days and the results were expressed as the dose of whole organisms required to kill half of the sensitized mice (the LD 50) calculated by the method of Reed \& Muench (1938). No mice died when given either the highest dose of vaccine alone or actinomycin $\mathrm{D}$ alone.

Assay for adjuvant activity. The method was based on that of Finger and his co-workers (Finger, Beneke \& Fresenius, 1970; Finger, Emmerling \& Brüss, 1970). Groups of five mice (Theiler's Original strain) were used; the adjuvant to be tested $(0.25 \mathrm{ml})$ was given intraperitoneally, followed by the antigen, $0.25 \mathrm{ml}$ of $\mathrm{I} / 2.5$ dilution of human group A whole blood in buffered saline. Seven weeks later the mice were bled out and the sera were prepared as already described; haemolysin titrations were done on plastic tiles by mixing $0.02 \mathrm{ml}$ volumes of test serum, I/5 guinea-pig serum, and a I \% (v/v) suspension of washed human group A red cells. All dilutions were made in buffered saline. The test was incubated for $90 \mathrm{~min}$ at $37^{\circ}$ and the tile read from above, by eye, using a $50 \%$ haemolysis end-point.

Immunodiffusion-precipitin tests. Ouchterlony plates were made by placing $\mathrm{I} \mathrm{ml}$ of $\mathrm{I} \cdot 5$ $(\mathrm{w} / \mathrm{v})$ New Zealand agar (containing $0.01 \%$ merthiolate) in an $8 \mathrm{~cm}$ plastic Petri dish. Plates were incubated at room temperature and $100 \%$ relative humidity for 2 to 4 days.

Preparation of lipopolysaccharides. These were prepared at the Lister Institute from acetone-dried Bordetella pertussis organisms of strain GL.29I by phenol + water extraction (MacLennan, 1960) and from the other strains by Dr L. Szabo of the University of Paris, who used a similar method. These materials were pyrogenic in rabbits (L. Szabo, personal communication) and were therefore presumed to be typical Gram-negative bacterial lipopolysaccharides.

Coupling of lipopolysaccharide to red-cell stromata. Red-cell stromata were prepared 
either from sheep blood or from human blood of groups $\mathrm{O}$ or A by the method of Staub (I964). Lipopolysaccharide (LPS) was coupled to stromata by mixing I mg LPS (which had been uniformly suspended in $5 \mathrm{ml}$ of buffered saline by $30 \mathrm{~s}$ treatment with a Dawe Soniprobe) with $\mathrm{I} \mathrm{ml}$ of packed stromata, and incubating the mixture at $37^{\circ}$ with gentle agitation for $30 \mathrm{~min}$. The coated stromata were centrifuged and washed three times with Io $\mathrm{ml}$ volumes of buffered saline, resuspended in $10 \mathrm{ml}$ of buffered saline containing $0.01 \%$ merthiolate, and heated at $56^{\circ}$ for $30 \mathrm{~min}$.

To enhance the efficacy of coupling, LPS ( $10 \mathrm{mg}$ ) was suspended in $20 \mathrm{ml}$ of $0.02 \mathrm{~N}-$ sodium hydroxide and kept at $37^{\circ}$ with gentle agitation for $\mathrm{I} 8 \mathrm{~h}$. At the end of the treatment all the material had dissolved; it was approximately neutralized by adding the theoretical amount of $0.2 \mathrm{~N}$-hydrochloric acid, and dialysed against several changes of buffered saline containing $0.01 \%$ merthiolate at 4 . The alkali-treated material was subsequently coupled to stromata in the same way as the untreated LPS.

Preparation of Bordetella pertussis endotoxin. A Boivin-type endotoxin was prepared from strains D6229 and D734 of Bordetella pertussis by trichloracetic acid extraction as described by Staub (1967), except that the ethanol precipitation was done at $4^{\circ}$.

Preparation of Escherichia coli conjugated protein. Escherichia coli strain NCTC 86 was grown for $18 \mathrm{~h}$ on nutrient agar at $37^{\circ}$, harvested and washed in saline; endotoxin was prepared as from Bordetella pertussis. Acetic acid was added to the endotoxin solution to a final concentration of $\mathrm{I} \%(\mathrm{v} / \mathrm{v})$ and the acidified material was kept at $100^{\circ}$ for $4 \mathrm{~h}$. After standing overnight at $4^{\circ}$, the small precipitate was centrifuged and purified by twice dissolving it in $0.05 \mathrm{~N}$-sodium hydroxide and reprecipitating by adjusting the $\mathrm{pH}$ to 4.0 with acetic acid. The final product was suspended in water and coupled to $B$. pertussis LPS by the method of Davies (1956) after estimating the protein content colorimetrically.

Analytical methods. Protein was measured by the Lowry, Rosebrough, Farr \& Randall (1951) modifications of the Folin-Ciocalteau method, using crystalline bovine serum albumin as standard. When appropriate, results were corrected for the interference produced by merthiolate. Dry weights were determined after drying samples at $105^{\circ}$ for $18 \mathrm{~h}$.

Preparation of anti-LPS sera. All preparations were injected intraperitoneally into mice of Theiler's Original strain. Lipopolysaccharide from Bordetella pertussis strain GL.29I, either alone, mixed with aluminium hydroxide ( $100 \mu \mathrm{g} /$ dose), coupled to Escherichia coli protein, or coupled, after treatment with alkali, to stromata, was given in one dose (of 0.2 , $\mathrm{I} \cdot 0,5 \cdot 0$, I0 or $100 \mu \mathrm{g})$, or in four doses $(2,5,5,5 \mu \mathrm{g})$ at weekly intervals. Lipopolysaccharide from all strains, including GL.29I, which had been coupled to stromata without prior treatment with alkali was given in seven weekly doses of $2,2,4,4,10,10,10 \mu \mathrm{g}$. All mice were bled out 2 weeks after their last injection and sera were prepared as already described.

Preparation of anti-endotoxin sera. These were prepared in the same way as the anti-LPS sera by injecting single doses of 3 to $70 \mu \mathrm{g}$ (dry wt).

\section{RESULTS}

The ability of killed whole-cell Bordetella pertussis vaccines to protect mice and to elicit bactericidal antibody is shown in Table $\mathrm{I}$, which demonstrates that organisms grown with nicotinic acid have lost the mouse-protective antigen, and that strain I34 is deficient in the antigen which elicits the complement-mediated bactericidal antibody (the 'bactericidal antigen'). Multiple doses of vaccines prepared from strain D6229 grown with nicotinic acid were completely devoid of protective antigen, but multiple doses of strain I34 organisms eventually gave bactericidal antibody titres at least as high as those induced by a single dose 
Table I. Protective potencies and bactericidal antibody titres induced in mice after single injections of whole-cell vaccine

Potency was assayed with doses of 2000,400 and $80 \times 10^{6}$ organisms. Five mice were removed from the highest-dose group just before challenge and the serum from these mice used for titrating the bactericidal antibody.

\begin{tabular}{lcc}
\multicolumn{1}{c}{ Strain } & $\begin{array}{c}\text { ImD } 50 \times 10^{-6} \\
\text { (organisms/mouse) }\end{array}$ & $\begin{array}{c}\text { Bactericidal } \\
\text { antibody } \\
\text { titre* }\end{array}$ \\
GL.29I & 500 & I 20 \\
D25525 & 640 & 480 \\
D25525/NA $\dagger$ & $\$ 2000$ & 480 \\
D6229 & 860 & I 20 \\
D6229/NA $\dagger$ & $\gg 2000$ & 480 \\
L84 phase I & 260 & 480 \\
L84 phase IV & $\gg 2000$ & 480 \\
I34 & 630 & $\ll 30$
\end{tabular}

* Reciprocal of highest dilution killing $80 \%$ of bacteria.

$\dagger$ Organisms grown with $500 \mu \mathrm{g}$ of nicotinic acid $/ \mathrm{ml}$.

Table 2. Protection of and bactericidal antibody titres in mice after multiple doses of whole-cell vaccine

\begin{tabular}{|c|c|c|c|c|}
\hline Strain & $\begin{array}{l}\text { No. of } \\
\text { organisms/ } \\
\text { dose }\end{array}$ & $\begin{array}{c}\text { No. of } \\
\text { doses }\end{array}$ & $\begin{array}{l}\text { No. of } \\
\text { survivors/ } \\
\text { number } \\
\text { challenged }\end{array}$ & $\begin{array}{c}\text { Bactericidal } \\
\text { antibody } \\
\text { titre* }^{*}\end{array}$ \\
\hline D6229/NA $\dagger$ & $2 \times 10^{9}$ & 6 & $0 / 10$ & 30,000 \\
\hline I 34 & $2 \times 10^{9}$ & 7 & N.D. & $I, 920$ \\
\hline
\end{tabular}

N.D. = Not done.

* Reciprocal of highest dilution killing $80 \%$ of bacteria.

$\uparrow$ Organisms grown with $500 \mu \mathrm{g}$ of nicotinic acid $/ \mathrm{ml}$.

Table 3. Protection of and bactericidal antibody titres in mice after multiple doses of Bordetella pertussis LPS on carriers

Strain from
which LPS
was prepared
GL.29I
GL.29I
GL.29I
D6229/NAt
I34
-
-

$\begin{array}{ccc}\text { No. of } & \begin{array}{c}\text { No. of } \\ \text { survivors/ } \\ \text { number } \\ \text { challenged }\end{array} & \begin{array}{c}\text { Bactericidal } \\ \text { antibody } \\ \text { titre* }\end{array}\end{array}$

$\begin{array}{lllc}\text { Escherichia coli protein } & 4 & \text { O/10 } & 480 \\ \text { Alkali stromata } \dagger & 4 & 3 / 10 & 1920 \\ \text { Stromata } & 7 & \text { I/8 } & 7680 \\ \text { Stromata } & 7 & \text { N.D. } & 7680 \\ \text { Stromata } & 7 & \text { N.D. } & <30 \\ \text { E. coli } \text { protein alone } & 4 & \text { N.D. } & <30 \\ \text { Human stromata alone } & 4 & \text { N.D. } & <30 \\ \text { Sheep stromata } & 4 & \text { N.D. } & 480\end{array}$

N.D. $=$ Not done.

* Reciprocal of highest dilution killing $80 \%$ of bacteria.

$\uparrow$ LPS treated with alkali before coupling to stromata.

$\leftarrow$ Organisms grown with $500 \mu \mathrm{g}$ of nicotinic acid $/ \mathrm{ml}$. 
Table 4. Protection of and bactericidal antibody titres in mice after single doses of Bordetella pertussis Boivin endotoxin

\begin{tabular}{|c|c|c|c|c|}
\hline $\begin{array}{l}\text { Parent } \\
\text { strain }\end{array}$ & Material & Dose & $\begin{array}{c}\text { No. of } \\
\text { survivors/ } \\
\text { number } \\
\text { challenged }\end{array}$ & $\begin{array}{c}\text { Bactericidal } \\
\text { antibody } \\
\text { titre }^{*}\end{array}$ \\
\hline D734 & Whole organisms & $2 \times 10^{9}$ & II $/ 13$ & 480 \\
\hline D734 & Endotoxin & $70 \mu \mathrm{g}$ & $2 / I 4$ & 480 \\
\hline D6229 & Endotoxin & $3 \mu \mathbf{g}$ & $2 / 14$ & 30 \\
\hline D6229 & Endotoxin & I $4 \mu \mathrm{g}$ & $4 / 15$ & 480 \\
\hline D6229 & Endotoxin & $70 \mu \mathrm{g}$ & $1 / 15$ & I 20 \\
\hline
\end{tabular}

of a typical strain (Table 2). Changing the route of injection and administering a single dose of $2 \times 10^{9}$ strain 134 organisms intravenously did not induce detectable bactericidal antibody; nor did an equivalent dose that had been sonically disrupted and mixed with human red-cell stromata.

Despite its atypical nutritional requirements, strain $I 34$ is in most other respects a typical phase I Bordetella pertussis strain, possessing, for example, histamine-sensitizing factor, haemagglutinin, agglutinogens, and protective antigen. Nevertheless, extraction of acetonedried organisms of this strain by the phenol + water procedure yielded only about onequarter of the normal amount of LPS (W. A. Vincent, personal communication), whereas bacteria grown with nicotinic acid yielded at least as much LPS as normal organisms.

These two sets of results suggested that the 'bactericidal antigen' might in fact be the Bordetella pertussis LPS, and attempts were therefore made to raise bactericidal antisera in mice with extracted LPS. However, this material was poorly antigenic, and single or divided doses of 0.2 to $100 \mu \mathrm{g}$ given either alone or with aluminium hydroxide as adjuvant failed to elicit any response. To improve its antigenicity, the LPS was coupled to red-cell stromata (with or without prior alkali treatment) or to the conjugated protein (Morgan, 1943) extracted from Escherichia coli strain NCTC86.

Table 3 gives the results of antibody production and mouse protection experiments with these materials. Sheep stromata alone induced moderate titres of bactericidal antibody; such antisera also gave a precipitin line with isolated pertussis LPS (see below). Human stromata prepared from either group $\mathrm{O}$ or group A blood gave no cross-reaction and were used for all coupling experiments.

A single dose of LPS + carrier never induced bactericidal antibody, even after treatment of LPS with alkali, a procedure which improves its ability to bind to stromata. (Since alkali treatment causes some loss of antigenic determinants from Salmonella typhimurium LPS (Čižnár \& Shands, 1970), it was not used routinely.) Five or seven doses of LPS from all strains examined, except strain I34, were sufficient to produce a serum with a bactericidal antibody titre at least as high as that given by a single dose of a normal vaccine strain. However, similar multiple doses of LPS + carrier did not protect mice (Table 3). Seven injections of either Escherichia coli protein or human stromata alone gave no detectable bactericidal antibody. A similar dosage of the material extracted by the Westphal procedure from strain 134 did not induce any bactericidal activity, a finding that accorded with the lack of effect of a single dose of whole-cell vaccine.

Extraction of Gram-negative organisms with hot phenol + water yields a highly degraded product containing very little protein; however, the much gentler cold trichloracetic acid 

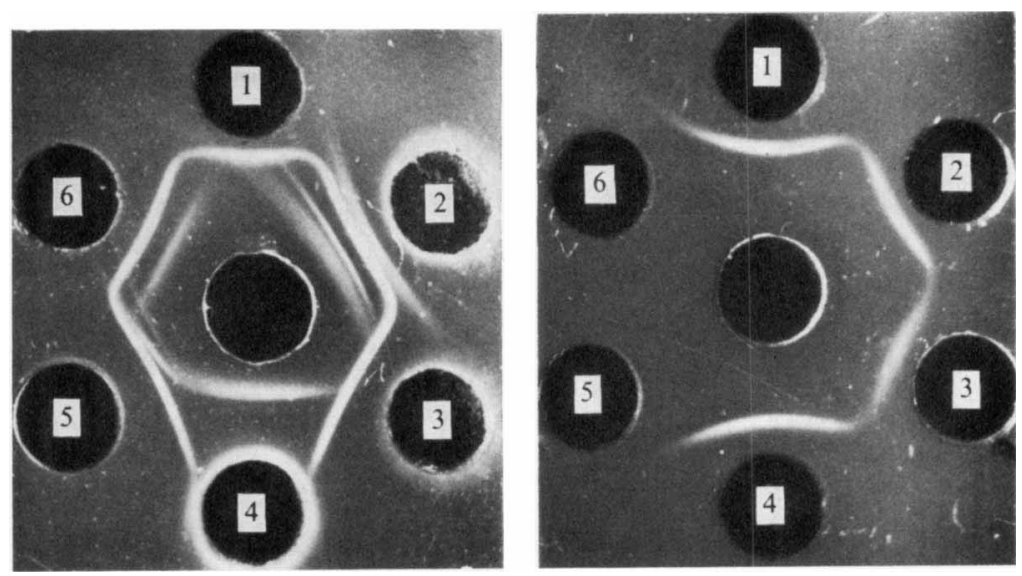

Fig. I. Identity of LPS from phase I Bordetella pertussis and precipitating antigens in supernatant liquids of sonicates $(S / N)$ from other strains in phases I and IV. Centre well: 6660, hyperimmune rabbit anti-pertussis serum. Outer wells: I, GL.29I LPS in saline; 2, D6229 S/N; 3, D6229/NA* $\mathrm{S} / \mathrm{N} ; 4, \mathrm{I} 34 \mathrm{~S} / \mathrm{N} ; 5, \mathrm{~L} 84$ phase I $\mathrm{S} / \mathrm{N} ; 6, \mathrm{~L} 84$ phase IV $\mathrm{S} / \mathrm{N}$.

Fig. 2. Identity of LPS from strains of Bordetella pertussis. Centre well: 6660, hyperimmune rabbit anti-pertussis serum. Outer wells: I, GL.29I LPS; 2, L84 phase IV LPS; 3, D6229/NA* LPS ; 4, GL.29I LPS; 5 and 6, I 34 LPS (two different preparations).

* Organisms grown with $500 \mu \mathrm{g}$ of nicotinic acid $/ \mathrm{ml}$.

method of Boivin gives a protein-containing product which is a much better antigen. A single dose of material extracted by this method from Bordetella pertussis strains D6229 and D734 induced bactericidal antibody, but did not confer significant protection (Table 4).

Further evidence of the connexion between LPS and the 'bactericidal antigen' was provided by immunodiffusion plates. When the supernatant liquid of a sonicate centrifuged at $20,000 \mathrm{~g}$ was tested against a rabbit hyperimmune antipertussis serum (denoted 666o, Dolby \& Dolby, 1969), a strong precipitin line was given by material from strains D6229, D25525 (grown with or without nicotinic acid), and L84 phase I or phase IV, but not by two separate lots prepared from organisms of strain I 34 (Fig. I). Moreover, this line was identical with the single line obtained by using GL.29 I LPS as antigen; sonicates from three other phase I strains gave the same strong precipitin line and single doses of them induced bactericidal antibody in mice.

The identity between the LPS present in all strains examined except 134 is also shown in Fig. 2; LPS from strains GL.29I, D6229 grown with nicotinic acid, and L84 phase IV, all gave a single identical line against serum 666o. Two lots of extract from strain $\mathrm{r} 34$ (two separate extractions) gave no line.

Similarly, when the mouse sera prepared by repeated doses of LPS coupled to stromata or to Escherichia coli protein were examined, all, with the exception of anti-I34 LPS, gave a single precipitin line against GL.29I LPS. Identical patterns were obtained when the centre well contained LPS extracted from D6229 (grown with or without nicotinic acid), L84 phase IV, or two other normal vaccine strains; with LPS from strain I34, no lines appeared.

The striking immunological difference between the LPS prepared from strain 134 
Table 5. Ability of Bordetella pertussis whole organisms and LPS to act as an adjuvant to haemolysin production in mice

Antigen, given to all mice, was $0.25 \mathrm{ml}$ of a $\mathbf{I} / 2.5$ dilution of human group A blood.

$\begin{array}{lllr}\text { Strain } & \text { Material } & \text { Dose } & \begin{array}{c}\text { Haemolysin } \\ \text { titre* }\end{array} \\ \text { D6229 } & \text { Organisms } & 3 \times 10^{9} & 80 \\ \text { D6229/NA } \dagger & \text { Organisms } & 3 \times 10^{9} & 80 \\ \text { L84 phase I } & \text { Organisms } & 3 \times 10^{9} & 160 \\ \text { L84 phase IV } & \text { Organisms } & 3 \times 10^{9} & 80 \\ \text { I34 } & \text { Organisms } & 3 \times 10^{9} & 160 \\ \text { GL.29I } & \text { LPS } & 100 \mu \mathrm{g} & 80 \\ & \text { Saline } & - & 10 \\ * \text { Reciprocal of highest dilution lysing } 50 \% \text { of the red cells. } \\ \dagger \text { Grown with } 500 \mu \mathrm{g} \text { of nicotinic acid/ml. }\end{array}$

organisms and that prepared from all other strains examined is emphasized by the fact that even serum from mice given as many as seven doses of I 34 whole-cell vaccine, although bactericidal (Table 2), did not give a precipitin line with any Bordetella pertussis LPS, including that extracted from strain I 34 itself.

Sheep stromata could not be used as carriers for LPS because injected alone into mice they induced bactericidal antibody. It is therefore interesting that with 6660 serum these stromata gave a precipitin line identical with that given by GL.29I LPS; moreover, the bactericidal serum produced by five injections of stromata alone gave a precipitin line against GL.29I LPS.

The Boivin-type endotoxin prepared from strains D734 and D6229 gave single strong lines against 6660 serum identical with that formed by GL.29I LPS.

In view of the close association between LPS and the 'bactericidal antigen', the endotoxin content of the whole-cell vaccines was assayed by measuring their toxicity in mice sensitized with $10 \mu \mathrm{g}$ of actinomycin D. The LD 50 of strain $\mathrm{I} 34$ was about four times that of $\mathrm{D}^{229}$ $\left(5 \cdot 3 \times 10^{8}\right.$ organisms compared with $\mathrm{I} \cdot 4 \times 10^{8}$ for $\left.\mathrm{D} 6229\right)$. Strain $\mathrm{D} 6229$ grown with nicotinic acid had an LD 50 similar to that of normally grown D6229, whilst L84 phases I and IV were both slightly more toxic (LD $50 \mathrm{I} \cdot 0 \times 10^{8}$ organisms).

The effectiveness of various strains as adjuvants to the production of haemolysin by mice was also investigated, since the adjuvant activity of Gram-negative organisms is believed to be related to their content of endotoxin. The results (Table 5) show that whole bacteria of strain I34 are as good an adjuvant as D6229, and that approximately the same effect is produced by $100 \mu \mathrm{g}$ of GL.29I LPS.

\section{DISCUSSION}

Since the report of the Medical Research Council trial (1956) there has been much interest in the mechanism by which the mouse is protected in the potency assay for Bordetella pertussis vaccines, and in the reason why the results of the test correlate with the ability of vaccines to protect children.

In mice challenged with 50,000 organisms of strain 18-323 the bacteria multiply on the ciliated epithelium of the brain for 3 days whether the mouse is immune or not (Berenbaum, Ungar \& Stevens, 1960; Dolby \& Standfast, 196I). In non-protected mice the bacteria continue to multiply until the viable count reaches $10^{7}$ to $10^{8}$ organisms/brain, when the 
animal dies; in mice which have been protected by active immunization, however, the viable count starts to decline at about 4 days after challenge, and by 7 to ro days after challenge the brain is sterile. At about the same time as the brain count in protected mice is beginning to decline the blood-brain barrier becomes permeable to bovine serum albumin (Berenbaum et al. 1960), to the dye Pontamine Sky Blue, and to human serum (Holt, Spasojevic, Dolby \& Standfast, 196r), and to horse gamma globulin (Iida, Kusano, Yamamoto \& Konosu, r966). The blood-brain barrier is normally impermeable to all these substances and, at least in the case of Pontamine Sky Blue, becomes so again in surviving mice at about the same time as the brain becomes sterile.

These results have naturally led to the suggestion that protection in vaccinated mice is due to a circulating antibody which cannot, however, gain access to the infecting organisms until the blood-brain barrier has been breached. Among the many antibodies induced by a whole-cell Bordetella pertussis vaccine, the obvious candidate for a protective antibody in such a mechanism is the complement-mediated bactericidal one; and a considerable amount of evidence indirectly supporting its involvement has been collected (Dolby \& Dolby, I969).

However, the results presented here seem to show that such a correlation must be fortuitous. Pusztai \& Joó (1967) found that Bordetella pertussis grown with $500 \mu \mathrm{g}$ of nicotinic acid/ml suffers a phenotypic loss of mouse-protective antigen; we have confirmed this observation, and have also demonstrated that as many as six spaced doses of such organisms were unable to protect mice. Nevertheless, one dose of bacteria grown with nicotinic acid induced bactericidal titres at least as high as those produced by normal protective strains. In addition, phase IV variants of normal vaccine strains, adapted to grow on simple media by repeated subculture (Leslie \& Gardner, I93I), still induced normal bactericidal antibody titres, although their ability to protect mice was almost, if not entirely, lost.

Conversely, one dose of $2 \times \mathrm{IO}^{9}$ organisms of strain 134 will protect mice well, without producing detectable bactericidal antibody. This antibody thus appears to be neither necessary nor sufficient for the protection of mice; whether protection is conferred by a different circulating antibody or by a cell-mediated process is not known.

Little is known of the chemical nature of the protective antigen, although it has been suggested to be a lipoprotein (Wardlaw, 1966; Ayme, Mynard, Donikian \& Triau, 1970; Sato, 1970). However, Pusztai, Csizér \& Joó (197I) produced evidence that the 'bactericidal antigen' may be the lipopolysaccharide. This is known to be the case with Neisseria gonorrhoeae (Glynn \& Ward, 1970) and the results in this paper support the suggestion that the same is true of Bordetella pertussis. The LPS prepared by the Westphal procedure is a poor antigen. In order to produce a bactericidal serum in rabbits, Pusztai, Csizér \& Joó administered repeated large doses (a total of 35 to $40 \mathrm{mg} /$ animal), the first three with Freund's complete adjuvant. Working with mice, we found that LPS coupled to either Escherichia coli conjugated protein or human red-cell stromata induced a high bactericidal titre after 4 to 7 spaced doses totalling $30 \mu \mathrm{g} /$ mouse. Only with a Boivin-type endotoxin, prepared by extraction with cold trichloracetic acid, could we induce bactericidal antibody after a single injection. Neither LPS on carrier nor Boivin-type endotoxin conferred any active protection against intracerebral challenge.

Pusztai and her colleagues were also unable to protect mice actively with LPS, although their hyperimmune rabbit serum would confer passive protection. However, passive protection does not necessarily involve the same mechanism as active protection: some types at least of passive protection are not correlated with active protection. These results will be reported elsewhere.

The Ouchterlony immunodiffusion technique gave a strong precipitin line, identical to 
that produced by isolated GL.29I LPS, from sonicates of all organisms that induced bactericidal antibody in mice, including L 84 phase IV. Moreover, the LPS isolated from these strains appeared to be homogeneous and identical by immunodiffusion; by contrast, the LPS isolated from strain I 34 was clearly different and did not give a precipitin line, even with an homologous antiserum. In addition, the Boivin-type antigens cross-reacted strongly with the isolated LPS as expected. Thus all strains of Bordetella pertussis examined, with the significant exception of strain 134 , seem to contain a common antigen, identical, in terms of the immunodiffusion test, with isolated LPS. All sera prepared against LPS combined with stromata, except that raised against I 34 LPS, gave a single anti-LPS precipitin line. Although there is thus a strong correlation between the presence of precipitating and bactericidal antibodies, the two are not identical, for the serum of mice given seven doses of strain 134 organisms, although now strongly bactericidal, did not give any precipitin lines against GL.29I LPS. MacLennan (I960) found that LPS extracted from phase IV $B$. pertussis did not cross-react with phase I LPS; however, the supposedly phase IV strain GI 54E (supplied to Dr MacLennan from the Elstree culture collection) is not in fact B. pertussis but a Brucella species.

The finding that mice given seven doses of strain 134 organisms developed appreciable bactericidal antibody titres indicates that this strain must possess some 'bactericidal antigen'.

We have suggested that the antigenic group which induces bactericidal antibody forms part of the bacterial endotoxin, and two possible explanations for the low 'bactericidal antigen' activity of strain I 34 are that it contains (i) only a very small amount of the whole Bordetella pertussis endotoxin, or (ii) a normal amount of an endotoxin in which the bactericidal antibody-inducing ability has been diminished. The latter would not necessarily affect the pharmacological properties of the bacterial endotoxin.

The endotoxin toxicity of strain 134, as measured in actinomycin D-sensitized mice (Pieroni \& Levine, 1970), was four times less than that of strain D6229, suggesting that I34 had a lower than normal content of endotoxin. Gram-negative organisms have a pronounced stimulatory effect on antibody production, and this adjuvant effect appears to be due to their endotoxin content (for a review, see Neter, 1969). Specifically, isolated Bordetella pertussis LPS has been shown to act as an adjuvant by Farthing \& Holt (1962) and by Nakase, Tateisi, Sekiya \& Kasuga (1970). The ability of strain I34 to increase the primary response of mice to human group A erythrocytes was therefore examined; this strain was found to be as good an adjuvant as any of the strains tested.

The evidence obtained so far therefore suggests that strain 134 possesses appreciable quantities of an endotoxin having at least some of the properties expected of such a material, and that its inability to induce bactericidal antibody is due to a loss of relevant immunological determinant group(s). An attempt by Dr L. Szabo to detect this loss by examination of the composition of isolated strain 134 LPS is now in progress.

It is now clear that bactericidal antibody is not involved in the protection of mice. Vaccine made from strain I34 protected both mice (Pillemer, I950) and children (Medical Research Council report, 1956). Vaccine made from strain 134 did not induce bactericidal antibody in mice unless given in a prolonged series of injections, but it did do so in rabbits much more readily; children may well be more like rabbits than mice in their ability to respond. Since strain $\mathrm{I} 34$ is not now in general use as a vaccine strain, the bactericidal antibody response of children cannot be tested directly.

There is at present no evidence to suggest that the mouse-protection test is not measuring the same antigen as that which protects children, and so it seems reasonably likely that 
bactericidal antibody production, if any, by vaccinated children would be of no value in protecting against subsequent infection. Certainly Dolby \& Stephens (unpublished findings) were unable to show any correlation in vaccinated children between the bactericidal antibody titres and their ability to avoid a subsequent attack of whooping cough.

A consequence of the lack of identity between the 'bactericidal' and protective antigens of Bordetella pertussis is that it is now not possible to contemplate replacing the expensive and time-consuming mouse-protection assay for vaccine potency by an assay for bactericidal antibody in vitro.

The authors thank the Medical Research Council for financial support; J.P.A. was in receipt of a grant while part of this work was in progress. They are grateful to Miss Claire Hilton and Mr R. Gandhi for technical assistance.

\section{REFERENCES}

Ayme, G., Mynard, M. C., Donikian, R. \& Triau, R. (1970). Attempts to prepare a non-cellular pertussis vaccine. Symposia Series in Immunobiological Standardization 13, 254-264.

Berenbaum, M. C., Ungar, J. \& Stevens, W. K. (1960). Intracranial infection of mice with Bordetella pertussis. Journal of General Microbiology 22, 31 3-322.

ČIžNÁR, I. \& SHANDS, J. W. JUn. (1970). Effect of alkali on the immunological reactivity of lipopolysaccharide from Salmonella typhimurium. Infection and Immunity 2, 549-555.

Cohen, S. M. \& WheELeR, M. W. (1946). Pertussis vaccine prepared with phase-I cultures grown in fluid medium. American Journal of Public Health 36, 37I-376.

Davies, D. A. L. (1956). A specific polysaccharide of Pasteurella pestis. Biochemical Journal 63, 105-1 16.

Dolby, J. M. (I965). The antibacterial effect of Bordetella pertussis antisera. Immunology 8, 484-498.

Dolby, J. M. \& Dolby, D. E. (1969). The antibody activities of $19 \mathrm{~S}$ and $7 \mathrm{~S}$ fractions from rabbit antisera to Bordetella pertussis. Immunology 16, 737-747.

Dolby, J. M. \& Standfast, A. F. B. (196I). The intracerebral infection of mice with Bordetella pertussis. Journal of Hygiene 59, 205-216.

DOLBY, J. M. \& VINCENT, W. A. (1965). Characterization of the antibodies responsible for the "bactericidal activity patterns' of antisera to Bordetella pertussis. Immunology 8, 499-5IO.

FARTHING, J. R. \& Holt, L. B. (1962). Experiments designed to determine the mechanism of the adjuvant activity of Gram-negative organisms upon antibody production. Journal of Hygiene 6o, 4I I-426.

Finger, H., BeneKe, G. \& Fresenius, H. (1970). Cellular kinetics of $19 \mathrm{~S}$ and $7 \mathrm{~S}$ hemolysin production in mice under the influence of bacterial endotoxins. Pathologia et Microbiologia 35, 324-337.

Finger, H., EMmerling, P. \& BRÜss, E. (I970). Variable adjuvant activity of Bordetella pertussis with respect to the primary and secondary immunization of mice. Infection and Immunity $\mathbf{I}, 25 \mathrm{I}-258$.

GLYNN, A. A. \& WARD, M. E. (1970). Nature and heterogeneity of the antigens of Neisseria gonorrhoeae involved in the serum bactericidal reaction. Infection and Immunity 2, I62-I68.

Holt, L. B., Spasojevic, V., Dolby, J. M. \& Standfast, A. F. B. (1961). Immunity in mice to an intracerebral challenge of Bordetella pertussis. Journal of Hygiene 59, 373-378.

Iida, T., Kusano, N., Yamamoto, A. \& Konosu, M. (1966). An immunofluorescence study of the action of antibody in experimental intracerebral infection of mice with Bordetellapertussis. Journal of Pathoiogy and Bacteriology 92, 359-367.

LesLIE, P. H. \& GARDNER, A. D. (193I). The phases of Haemophilus pertussis. Journal of Hygiene 3I, 423-434.

Lowry, O. H., Rosebrough, N. J., Farr, A. L. \& Randall, R. J. (I95I). Protein measurement with the Folin phenol reagent. Journal of Biological Chemistry 193, 265-275.

MacLennan, A. P. (I960). Specific lipopolysaccharides of Bordetella. Biochemical Journal 74, 398-409.

MEDICAL RESEARCH COUNCIL. (1956). Vaccination against whooping cough. Relation between protection tests in children and results of laboratory tests. British Medical Journal 2, 454-462.

Miles, A. A. \& MisRa, S. S. (1938). The estimation of the bactericidal power of the blood. Journal of Hygiene 38, 732-749.

Morgan, W. T. J. (1943). An artificial antigen with blood group A specificity. British Journal of Experimental Pathology 24, 4I-49. 
Nakase, Y., TAteisi, M., Sekiya, K. \& Kasuga, T. (1970). Chemical and biological properties of the purified $\mathrm{O}$ antigen of Bordetella pertussis. Japanese Journal of Microbiology 14, I-8.

NetEr, E. (1969). Endotoxins and the immune response. Current Topics in Microbiology and Immunology 47, 82-124.

Pieroni, R. E. \& LeVINe, L. (1970). Use of actinomycin D for quantitation of endotoxin in pertussis vaccine and extracts. Symposia Series in Immunobiological Standardization 13, 198-202.

Pillemer, L. (1950). Adsorption of protective antigen of Haemophilus pertussis on human red cell stromata. Proceedings of the Society for Experimental Biology and Medicine 75, 704-705.

Pillemer, L., Blum, L. \& Lepow, I. H. (1954). Protective antigen of Haemophilus pertussis. Lancet i, I257I 260 .

PuszTAI, Z., Csizér, Z. \& Joó, I. (I97I). The role and specificity of Bordetella lipopolysaccharide in immune reactions. Zeitschrift für Immunitätsforschung I4I, I 29-I4I.

Pusztai, Z. \& Joó, I. (1967). Influence of nicotinic acid on the antigenic structure of Bordetella pertussis. Annales Immunologiae Hungaricae ro, 63-67.

REED, L. J. \& MUENCH, H. (1938). A simple method of estimating fifty per cent endpoints. American Journal of Hygiene 27, 493-497.

SATo, Y. (1970). Isolation and some properties of the protective antigen from Bordetella pertussis. Symposia Series in Immunobiological Standardization 13, 214-220.

STAUb, A. M. (1964). The role of the polysaccharide moiety in determining the specificity and immunological activity of the O-antigen complex of Salmonellae. In Bacterial Endotoxins, pp. 38-48. Edited byM. Landy \& W. Braun. New Brunswick, New Jersey: Rutgers University Press.

Staub, A. M. (1967). Preparation of cell wall antigens from Gram-negative bacteria. Methods in Immunology and Immunochemistry $\mathrm{r}, 28-34$.

Wardlaw, A. C. (1966). Purified pertussis immunogen: a progress report. Symposia Series in Immunobiological Standardization 3, 99-1 I8. 